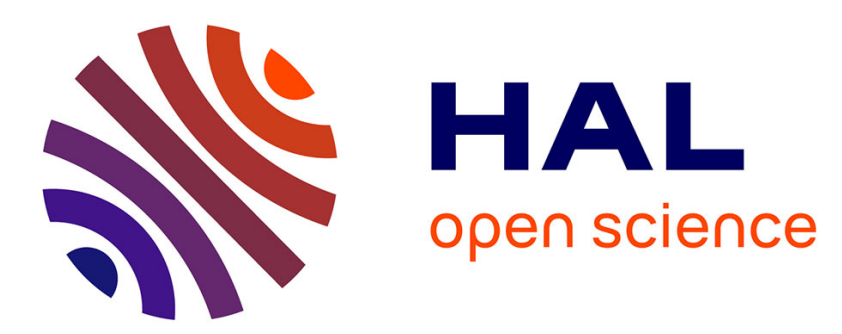

\title{
Significance and applications of nanoparticles in siRNA delivery for cancer therapy
}

\author{
Hafiz Muhammad Ali, Giorgia Urbinati, Mouna Raouane, Liliane
}

Massaad-Massade

\section{- To cite this version:}

Hafiz Muhammad Ali, Giorgia Urbinati, Mouna Raouane, Liliane Massaad-Massade. Significance and applications of nanoparticles in siRNA delivery for cancer therapy. Expert Review of Clinical Pharmacology, 2014, 5 (4), pp.403-412. 10.1586/ecp.12.33 . hal-02330005

\section{HAL Id: hal-02330005 https://hal.science/hal-02330005}

Submitted on 12 Oct 2021

HAL is a multi-disciplinary open access archive for the deposit and dissemination of scientific research documents, whether they are published or not. The documents may come from teaching and research institutions in France or abroad, or from public or private research centers.
L'archive ouverte pluridisciplinaire HAL, est destinée au dépôt et à la diffusion de documents scientifiques de niveau recherche, publiés ou non, émanant des établissements d'enseignement et de recherche français ou étrangers, des laboratoires publics ou privés. 
archives-ouvertes

\title{
Significance and applications of nanoparticles in siRNA delivery for cancer therapy
}

\author{
Hafiz Muhammad Ali, Giorgia Urbinati, Mouna Raouane, Liliane
}

Massaad-Massade

\section{To cite this version:}

Hafiz Muhammad Ali, Giorgia Urbinati, Mouna Raouane, Liliane Massaad-Massade. Significance and applications of nanoparticles in siRNA delivery for cancer therapy. Expert Review of Clinical Pharmacology, Informa Plc, 2014, 5 (4), pp.403-412. 10.1586/ecp.12.33 . hal-02330005

\section{HAL Id: hal-02330005 \\ https://hal.archives-ouvertes.fr/hal-02330005}

Submitted on 12 Oct 2021

HAL is a multi-disciplinary open access archive for the deposit and dissemination of scientific research documents, whether they are published or not. The documents may come from teaching and research institutions in France or abroad, or from public or private research centers.
L'archive ouverte pluridisciplinaire HAL, est destinée au dépôt et à la diffusion de documents scientifiques de niveau recherche, publiés ou non, émanant des établissements d'enseignement et de recherche français ou étrangers, des laboratoires publics ou privés. 


\section{Significance and applications of nanoparticles in siRNA delivery for cancer therapy}

\author{
Hafiz Muhammad \\ Ali, Giorgia Urbinati, \\ Mouna Raouane \\ and Liliane \\ Massaad-Massade* \\ UMR CNRS 8203. Institut Gustave \\ Roussy, 114 rue Elouard Vaillant, \\ 94805 Villejuit, France \\ *Author for correspondence: \\ Tel: : +33142115128 \\ litiane.massadegigr.fr
}

RNAi is a powerful gene silencing process that holds great promise in cancer therapy by the use of SiRNA. The aim of this review is to give an outline on different approaches to deliver siRNA and to describe the advantages and demerits of these systems. The prospects for SiRNA are to be substantially better than other therapies, as they are easily applicable to any therapeutic target. They also promise potent gene inhibition with exquisite selectivity down to the level of single nucleotide polymorphism, and can easily identify offending proteins or variants by screening across gene sequence. The main obstacle of using RNAi technology in cancer treatment is to protect such a fragile and quickly metabolized biological molecule and to efficiently deliver it in vivo, to the target cells. Therefore, there is a need of new systems, as nanoparticles for siRNA delivery, to reach and improve their biodistribution in target tissue.

KEYWORDS: cancer therapy • delivery systems • nanoparticles • SIRNA

Deregulation of gene expression is a common feature in cancer. The possibility to inhibit the expression of an oncogene at the mRNA level, instead of blocking the function of the gene product, has elicited a great interest for a long time as potential therapeutic application. Therefore, RNAi offers promising new opportunities to very specifically carget the genes deregulated in various pathologies including cancer. This strategy has been proposed as a royal road to block EWS-Flil gene expression in Ewing sarcoma (1,2), RET/PTC in papillary thyroid carcinoma (3), HER2 in nasopharyngeal tumor [4], $V E G F$ in tumor angiogenesis [5,6], $P D$ L.] in ovarian cancers [ 7 ) and $F A K$ in pancreatic adenocarcinoma [8;. However, in vivo delivery of siRNA is a key challenge because the biological efficacy of the siRNAs is hampered by their short plasmatic half-life due to poor stability in biological Auids and low intracellular penemation due to their highly hyctrophilic character [i]. So far, a wide variery of approaches including viral vecror-based and nonviral delivery systems such as liposomes, nanoparticles (NPS), lipophilic conjugares, polymers and cell-penerating peptides $[10,1]]$ have been investigated to enhance taiget cells' uprake and silencing porency in wivo. However, the safecy of viral vectors is questionable due to immunogenicity and possible recombination with oncogenes. Most of the nonviral vectors are designed using polycations, either polymers or lipids whom (cyto) toxicity is now well documented [12]. Therefore, it is an urgent need to introduce new concepts able to impact on the way of siRNA delivery based on the use of more efficient and safe (bio) materials for drug delivery purpose such as squalene, a cholesterol precursor. In this review, the authors describe the major types of Nl's that are used to vectorize siRNA, and also their advantages and disadvantages.

\section{Benefits \& drawbacks of RNAi in cancer treatment}

Antisense oligonucleorides (AS-ONs) and RNAi are the major approaches for therapeutic inhibicion of gene expression. Nichough the activity of both zypes of molecules is due to their base pairing capacity with complementary cellular nucleic acids, the merhod by which they inhibit gene expression is different. AS-ONS are single-stranded DNA or RNA sequences of 13 -.25 bases that can highly selectively inhibit the expression of a arget genes by kybridizing with their specific 'sense' sequences in mRNA or DNA molecules 13:. RNase H-mediaced degradation of complementary mRNA is the major mode of acion of AS. ONS. This entyme 
specifically cleaves the RNA strand of RNA-DNA heteroduplexes, leading to the release of the AS-ON that can further bind to a new mRNA strand; the mechanism is therefore catalytic [14]. Whereas, siRNAs are RNA duplexes of 21-23 nucleotides with approximately 2 nucleotides 3 overhangs. One of the siRNA strands, named the guide strand, is recognized by the RNAinduced silencing complex RISC in which the main actor is Ago2 procein (hAGO2 in human). The guide strand serves as a template for the recognition of homologous $m R N A$, which upon binding to RNA-induced silencing complex, is cleaved by the catalytic activity of Ago2. The other siRNA strand, the passenger strand, is degraded.

It is well known that siRNA and AS-ON can inhibit their specific targets genes, and thercfore used for the treatment of many diseases including cancer (15). Their high specificity, covcring a wide range of biomedical applications, allows the inhibition of target proteins that are not easily accessed and modulated by conventional small molecular weight or protein drugs [16]. However, application of gene silencing via ONs faces obstacles in gene transfection and tissue targering [17) because of their poor in vivo stability and their inabilicy to transverse intact cell membranes to any significant degree due to their highly hydrophilic and anionic character (18). Thus, che development of an ef ficient delivery system is one of the most challenging hurdles to turn $O N_{s}$ into clinically acceptable therapeutic drugs.

The primary obstacle for translating RNAi technology from an effective research tool inco a feasible therapeucic strategy is the efficient delivery of these molecules to the target cells in vivo. There is no nacural mechanism for the highly hydrophilic polyanionic macromolecules to traverse the cellular membrane due to the reason that the bioavailability of these agents in the intracellular comparcment is minuscule. The efficacy of siRNA into cells is of fended by the major biological barriers, along with their transient gene silencing effects due to their short-lived nature, and conditioned by the growth porential of dividing cells between 36 and $48 \mathrm{~h}$ for rapidly diving cells and around several weeks for slowly dividing cells) \{19\}.

Another key barrier for the arrival of ONs to the target area in the body is the phagocytes of the reticuloendorhelial system. These cells monitor the blood, remove foreign materials such as bacteria and viruses and tend to treat administered macromolecules such as ONs as foreign materials, thus accumulating chese materials in hepatic Kupffer cells, splenic macrophages and orher phagocyte-rich sices $\{20\}$. In addition, naked AS-ONs and si RNAs are relatively unstable in the blood in their native forms, as they are degraded by nucleases due to short halfilife of few minutes, and are rapidly cleared from che body by renal excretion or may also aggregate with serum proteins \{21\}. In parailet, the systemic exposure of siRNA can also induce some nonspecific responses that are caused by $\mathrm{Cp}$ (; I)NA oligonucleorides 22 ? . Passing through the vasculature, ONs must disseminate through the extracellular matrix ECM, which is a dense newwork of polysaccharides and fibrous proteins that also hinder ONS' diffusion towards the target cells [2.3). 'Thus, the revolutionary porency and selectivicy of siRNA can enable improved targeted cancer therapeutics; but the appropriate means of systemic administration and targeted distribution to disseminated metastatic lesions is needed [6].

\section{Strategies to transport gene silencers}

A wide variety of approaches including viral and nonviral delivery systems have been investigated to enhance the target cell siRNA-uptake and silencing potency in vivo.

\section{Viral vectors}

Viral vectors are the most powerful tool for gene transfection. The use of viral vectors is known to be the best way to deliver ON within the cells. Recently, they have been used to deliver siRNA for silencing the hemagglutinating virus of Japan (also called Sendai virus) [24]. However, the safery of viral vectors is questionable due to immunogenicity and possible recombination with oncogenes [25], a general lack of specificity and gene delivery to the target cells of interest, potential toxicity of the viral vectors themselves (26) and even some of them are also able to infect nondividing cells [27].

\section{Nonviral vectors}

Nonviral vectors are alternative to viral vectors. Many nonviral vecrors have been designed and have become a powerful and popular research tool to elucidate gene structure, regulation and function. Although less efficient than viruses for gene delivery, they offer several advantages: particularly, simple to use, offer trouble-free quality control, biocompatibility and generate little or no specific immune response [28].

Two major nonviral approaches, based on either chemical modification or nanoformularion, were adopted to overcome the above-mentioned limitations concerning ONs' administration. The chemical approach consists of either synthesizing nucleic acids with variations in their natural structure (in order to improve resistance towards degradation) (11) and/or attaching a lipidic, peptidic or polymer moiety associated or nonassociated with a cell-targering ligand. Attachment of specific targeting ligands can induce binding to protein carriers or uptake by the desired populacion of cells to be treated. siRNAs can be: coupled with fusogenic peptides, linked to anribodies against cell surface receptor ligands for cell-specific delivery, encapsulated in lipid complexes or cationic liposomes or incorporated in polymers that can be chemically different and able to form NPs (29). Certain amine-containing cationic polymers such as polyechyleneimine (PEI) can be attached as ligands to the surface of NPs through standard conjugation chemisury. These carionic polymers are capable of inducing membrane permeability, facilitating the entry of NDS into the cells. In particular, PEI has been widely investigated for gene delivery because of its ability to complex with and condenses DNA and transfect a broad range of cell lines with high efficiency (20).

A polymer combining PEl with the biocompatible polymet polyethylene glycol (PEC; adaman tine-PE(3) and the polysaccharide chitosan were attached to the surface of iron oxide NPs for in wimo gene delivery [30). The proton sponge effect was used to deliver siRNA-wrapped quancum dors inco MDAMB-231 breast cancer cells. By coating quantum dors with a balanced composition of 
tertiary amine and carboxylic acid groups, NPs with their siRNA cargo were capable to penerrate cell membrane, released from endosome, carrier unpacking and intracellular transport of cargo (31). NPs functionalized with a tumor-homing peptide and siRNA cargo have been shown to incernalize the cell by ligand-mediated internalization and knockdown of EGFP signal in EGFP'-transfected HeLa cells [32]. Aptamers can also be coared onto the surface of NPs for in vivo and in vitro targecing. Aptamers are short single-stranded DNA or RNA oligonucleotides selected in vitro to specife cellular targets with high selectivity and sensitivity [33).

Coupling dual antibodies (the murine 83-14 MAb to the human insulin recepter and the rat $8 \mathrm{D} 3 \mathrm{MAb}$ to the mouse transferrin recepto:) to siRNA EGFR at the distal end of PEG on a sterically stabilized liposome by a complex procedure reduced tumor expression of immunoreacrive EGFR. Moreover, an increase in survival time of mice with advanced intracranial braincancer was observed (34). Several ef forts were carried out to evaluate cationic lipids and polymers activiries, originally developed from plasmids internalized by nonspecific electrostatic interactions [35]. These plasmids had a good cytoplasmic delivery, but their functional activities remained lim ited due to the poor entry into the nucleus.

Conjugation of nucleic acids with neutral lipids provides greater metabolic stability and improved bioavailability and offers an interesting alternative [3]. It has been reported that this approach could significancly enhance cellular uptake of AS-ONs and siRNAs, prolong the half-life of these molecules in plasma and increase the efficiency of siRNA-induced gene silencing in vivo. Thus, the potential advantages of the chemical strategies are as follows: ON preferential targering towards specific tissues and cells, expressing specific receprors delivery of $O N$ to appropriate intracellular compartments (i.e., cytoplasm or nucleus), better ON way out from the blood and widespread distribution in tissues due to the small size of the chemical conjugates (36).

A wide variety of nanocarriers, such as liposomes [10]. NPs [37]. micelles [5] and polyplexes [38], have been investigated so far to enhance target cells' siRNA uptake and silencing potency' in vivo. Chitosan, a positively charged polysaccharide containing nonacetylated $\beta$-linked D-glucosamine residues, has been intensively investigated as a nucleic acid delivery system and has been successfully urilized for in vino delivery of siRNA as chicosan-based (2) or core-shell type (core of poly(isobutylcyanoacrylate) polymer and shell of chitosan] (39) NP. To enhance the circulation half-life, these colloidal systems have been decorated with PEG chains.

Morcover, to improve target cell specificity, Dubey et al. decided to graft l-argingl-glycyl-1-aspartic peptide to bind to the integrins on the tumor neovasculature (40). For example, the intravenous injection of these NPs cont aining siRNA dirceted against VEGF receptor-2 led to the selective uptake into subcutancous tumor xenografts and reduced both rumor growth and angiogenesis [5].

\section{Requirements of nanoformulations}

ONs must pass through the cight vascular endorhelial juncrions (o) leave the blood circulation, but the molecules larger than $5 \mathrm{~nm}$ in diameter can not readily cross the capillary endothelium. In contrast to the nomal endothelium, the tumor vasculatures are leakier and characterized by discontinuous structures where pore size varies from 100 to $780 \mathrm{~nm}$, and has a poor lymphatic drainage compared with the pore size of less than $2 \mathrm{~nm}$ in normal vascular endothelium in most tissues and postcapillary veins $(6 \mathrm{~nm})$ [41].The tumor endothelium may allow the penetration of high molecular mass macromolecules ( $>40 \mathrm{kDa}$ ) and NPs up co approximately $200 \mathrm{~nm}$ in diameter by the translocation process known as the 'enhanced permeation and retention' (EPR) effect [42]. Moreover, on cellular internalization, the ONs must be released from the endosomes (e.g., siRNA loaded on to dicer/Ago-2) to reach the intracellular relevant targets [43]. As the condition in the endosomes/yosomes is mildly acidic, the acid responsive delivery carriers cause facilitated cytosolic release of ONs, and thus has been a popular strategy to overcome this intracellular hurdle [44]. Several sudies showed that naked siRNA are inefficient because of their fast metabolism; therefore, there is a need to protect them against degradation (for review [45]). In a nucshell, an effective delivery strategy must take into account the need to protect the ONs from the enzymatic digestion, improve the pharmacokinetics by avoiding excretion via the reticuloendorhelial system and rapid renal filtration, allow a better cranslocarion through the endothelium, facilitare the diffusion through the extracellular matrix, enhance cellular uptake and allow endolysosomal escape [29].

\section{Choice of nanodelivery system}

The interaction of NPs with cellular structures is affected by mulciple factors including the intrinsic properties of NPs, target cell type and its physiological state, cellular uprake, toxicity and intraceflular localization. During particle-cell interaction, lipid domains, enzymes, carbohydrates and protein receptors of plasma membrane interact differently with the different types of NPs coming in contact with the plasma membrane co ultimatcly determine the cellular response towards the material. Particle size, morphology and position on the membrane surface decide the various forces of interactions, lead to divergent cellular responses and thus differene roures of uptake. For in vivo applications, the engineered NPs need to overcome additional biological barriers before being aken up by the targeted cells such as evading undesired immune responses, maintaining colloidal stability in blood circulation, extravasation into the targeted organs and achieving effective tissue penetration [46]. Keeping in view the complexicy of NPs' cell interaction and the diverse and sequential presentation of biological barriers on the cellular and the tissue level, NPs need to be designed with dymamically triggered or activated functions or properties 229:. Physicochemical properties of the engineered NPs should be considered while designing a nanomedicine for optinal intracellular uptake and targeting with an aim of being capable ro reach its biological targer with high efficiency and specificity.

\section{Types \& forms of NPS}

The nanodelivery system generally' uses cationic lipids or polymers that interact with ONs through electrostatic interactions, leading to manoplexes wich size between ten and few hundred nanometers. The expected advantages of the nanoformulation approach are a better stability in biokegical fuids and an improved cell penctration 
and tissue biodistribution. This strategy has already achieved significant success in both cellular and animal studies [47]. However, the toxicity of cationic transfectants either lipidic or polymeric may raise major issues for clinical utilization [25]. In this context, the use of nonionic lipids for $\mathrm{ONs}$ ' delivery represen rs an attractive methodology as many lipids are safe, nontoxic and biocompatible, additionally some of then being of natural origin [48].

Four major cypes of NPs are known to deliver the oligonucleotides: nanoplexes, polyplexes, lipoplexes and micelles (Fıun: 1). The following paragraphs will describe briefly the characceristics of each type. Few examples are summarised in TasL: 1 .

Nanoplexes: either nanosphere, where nucleic acid is associated with the nanoparticle, or nanocapsule, where nucleic acid is encapulated into the nanoparticle;

- Polyplexes: core-shell type nanoparticles;

- Lipoplexes: liposome structures characterized by a bilayer lipid membrane and

- Micelles: the results of electrostatic interaction between nucleic acids and copolymers.

\section{Nanoplexes}

Two types of nanoplexes can be described: nanospheres where the nucleic acid is dispersed throughout the particle or adsorbed on the surface and nanocapsules where the nucleic acid is encapsulated inside the particle. 'The authors' laboratory developed two types of nanospheres: type $1(139 \pm 47 \mathrm{~nm}$ size and $1.6 \mathrm{mV} \zeta$ potential) and type $2(65 \pm 17 \mathrm{~nm}$ size and $21 \mathrm{mV} \zeta$ potential) were prepared by combining polyalkyl cyanoacrylate (as biodegradable polymer matrix) and chitosan (as a cation). The nanospheres were loaded with oligonucleotides to target EWS-Fli-1 junction oncogene in Ewing sarcoma [2]. In type I nanospheres, chitosan was just overcoated; whereas in type 2, it was covalently bound to PACA.

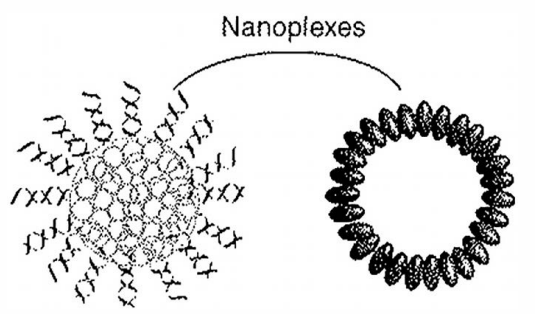

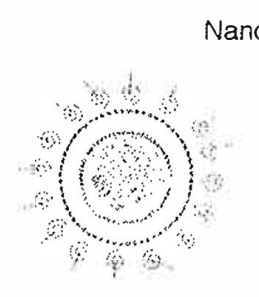

Polyplex
Nanocapsule

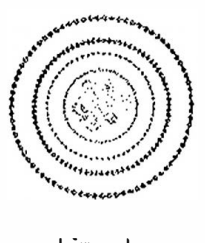

Lipoplex
Chitosan has been chosen as it has the advantage over cetyltrimethylammonium bromide of being less toxic and allowing higher ON loading. When these NI's were intratu morally injected, the authors observed that both types of nanospheres significantly reduce tumor growth and partially decrease the mRNA expression [2].

\section{Polyplexes (core-shell type NPs)}

In the core-shell type of NPs, the core consisted of the biodegradable poly isobutylcyanoacrylate polymer and the shell of chitosan (linear polysaccharide composed of randomly distributed $\beta$-(1-4)-linked D-glucosamine and $N$-acetyl-D)-glucosamine) for the treatment of papillary thyroid carcinoma. The tumor growth was almost stopped after intravenous injection of the antisense siRNA-loaded NPs in contrast to all control experiments where 10-times increase in tumor size was observed $\{49\}$.

\section{Lipoplexes}

Liposome's structure is characterized by a bilayer lipid membrane mostly composed of phospholipids that can be neutral, positively or negatively charged. Liposomes are being clinically used for chemotherapy and other delivery systems, and are forms of NPs that function as carriers and act as a slow release depot for the drug in the diseased tissue. Usually, a low amount of cationic lipids is added to the formulation to increase charge interactions between the $\mathrm{ON}$ and the vehicle rendering the nanoformulation more stable. Moreover, cationic lipids should improve cellular uptake. For example, Sorensen $e$ tal. showed the reduction of TNF- $\alpha$ expression in the liver and the spleen by delivering siRNA packaged in cationic liposomes (50). 1, 2-Dioleoylsn-glycero-3-phosphatidylcholine (DOPC) is a neutral lipid, and is successful to deliver AS-ONs in vivo without toxicity. DOPC liposomes were used to deliver gene-specific siRNA in orthotopic ovarian cancer models [51]. Specific FAK siRNA in DOPC liposomes was systemically delivered and resulted in efficient FAK downregulation and therapentic efficacy compared wicla naked siRNA or cationic liposomes. Treatment with FAK siRNA-DOPC plus either docetaxel or cisplatin chemotherapy was highly effective in inhibiting ovarian cancer growth even in patients with chemotherapy-resistant tumors [i]. This delivery system is not tissue specific, but furcher liposomes' modifications allow cumor-selective targeting [40].

\section{Micelles}

Micelle-forming copolymers such as PEG-polycation di-block polymers with diamine side chains were used as endosome escaping carriers for siRNA [52]. Other rypes of polymeric micelles designed for nucleic acid delivery include PEC-poly aspartic acid copolymers 15.3) (exert a 'proton sponge' effect in endosomes), lactosylated PEG (form complexes with poly lysine and AS-ODN thus allow targering to galactose receptors in liver cells) isal and PEG-poly nethylmethacrylate block copolymers used to produce hybrid organic inorganic NPs [36].

Kim (\% al. spontancously obrained micelles afier conjugation of poly (ethylene glycol) (PEG)-conjugated to VEGF siRNA ( core of the siRNA VEGF/PEB w wh a surounding PEG shell layer.

Figure1. Four major types of nano articles that are used to deliver oligonucleosides. 


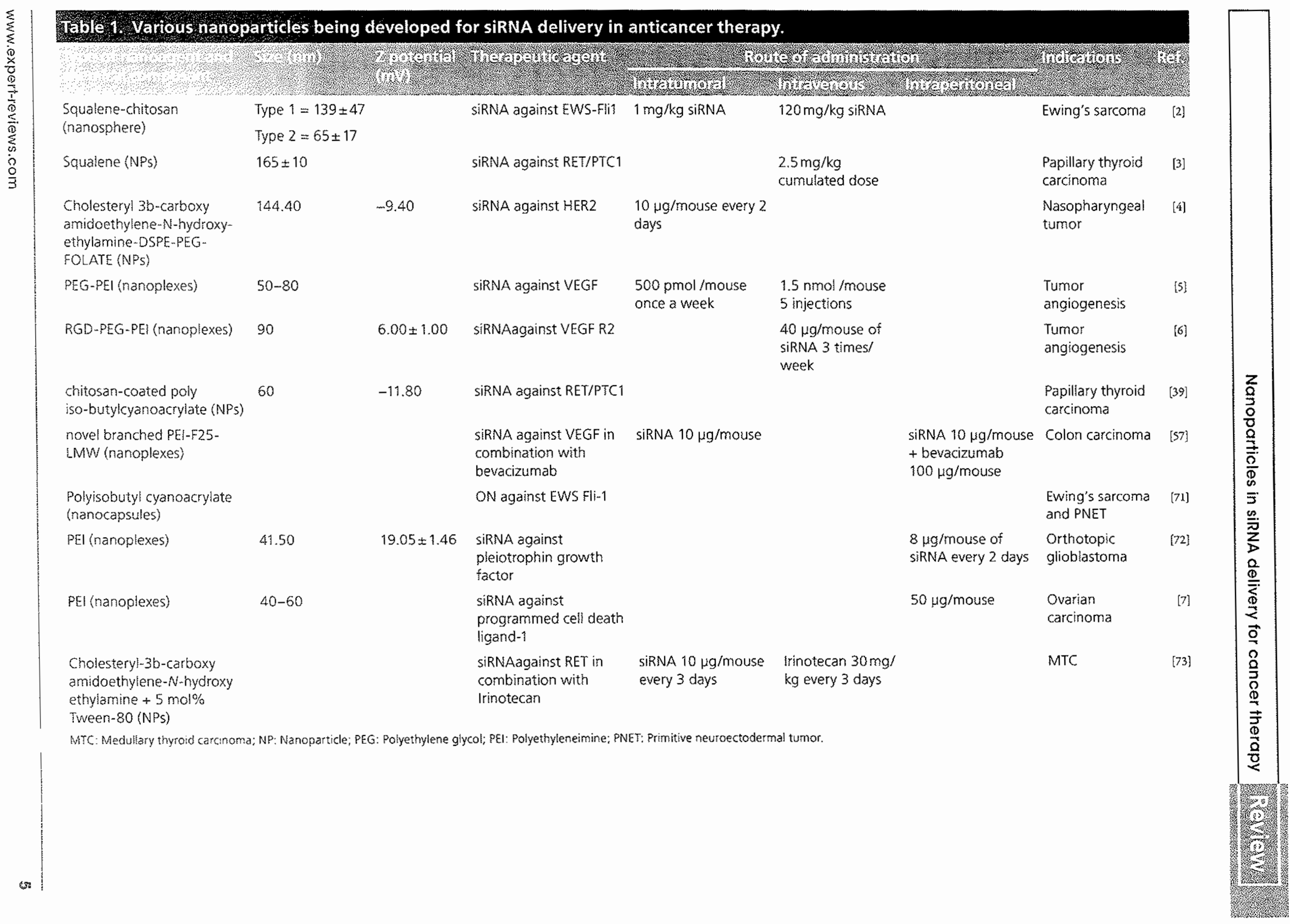


After intravenous and intratumoral treatments of xenografted human prostate carcinoma, they observed a significant decrease of tumor growth and an inhibition of VEGF expression [5]. The biodistribution on incravenous injection was further studied and compared with the cationic liposome formulation 1,2-dioleyl3-trimethylammonium-propa neldioleoylphosphatidylethanolamine. Notably, the different carriers changed the intratumoral distribution of siRNA within the cumor [37].

\section{Demerits of delivery services \\ Dependency on dose \& route of administration}

One of the most important parameter to be considered for siRNA efficiency is the optimal dose able to in hibit the target gene. Hassani et al. demonstrated efficient delivery of nucleic acids to cells by jetPEI, but, when was used to introduce siRNA into the mouse brain in vivo, no gene silencing activity was observed in the low-dose ranges tested. This suggests that siRNA dose dependency is fundamental to obtain a cherapeut ic effect [55].

Several routes of administration were suggested: intranasal administration, intratracheal instillation, aerosol delivery and intravenous injection. It seems that the route must be properly chosen regarding the targered tissue, for example, for lungs, aerosol keeps long persistence gene expression when compared with instillation [56].

The systemic delivery of siRNA targeting the tumor VEGF resulted marked in antitumor effects in subcutaneous prostate and pancreatic carcinoma xenografts in mice upon intraperitoneal compared with intravenous administration of the PEI F25LMW/siRNA complexes. Downregulation of VEGF expression on $m R N A$ and protein levels were comparable to the treatment with the cherapeutic humanized anti-VEGF antibody bevaci zumab (Avastin $\left.{ }^{(}\right)$[57]. Similarly, the administration through the aail vein, in contrast to incrapericoneal in jection, resulted in high siRNA levels in mouse lungs [58].

\section{Charge \& size of the delivery system}

In the late 1980s, several scudies have been performed to assess the physical-chemical properties of different nanosystems' deliveries. It has been shown that charge and size play a key role for passive targecing. For example, positively charged NP's are known to improve the interaction with the bloodstream components reducing the halflife of drugs. As a result, there is rapid clearance of these delivery vehicles from the bloodstream compared with near-neutral particles exhibiting reduced phagocytic uptake [59]. Negatively charged liposomes were believed to be more rapidly' removed from circulation than neutral or positively charged liposomes. Kostarelos et al. showed that the negatively charged lipids affect the rate of liposome uptake by the reticuloendothelial system. Moreover, phosphatidydserine, phosphatidic acid and phosphatidyl glyeerol containing liposomes are cleared more rapidify than neutral liposones.

'The size of NPs shouk be between 40 and $200 \mathrm{~nm}$ depending on the targeting tissues. The characteristic solid tumors have higher interstisial flud pressure in the center of the tumor compared with the periplyery. An ourward convective flow reduces drug diffusion to the center of the cumor, and the parricles and drugs that gain interstitial access have higher ectention times than in normal rissues. This aberrant vasculature and higher intersticial fuid pressure create an EPR) effect on NPs. Particles that are smaller than the fenestration can gain access and be retained in the tumor $(60.61\}$. Thus, the macromolecule complexes preferentially accumulate in tumors through the EPR effect. However, these large macronolecules exhibit limited diffusion into the extracellular spaces such as tumor interstitium and in the complex intracellular environment [62]. In both situations, restricted movement will severely limir efficacy by preventing uptake by a sufficient number of cells or hindering the ability of the delivered particles to localize in to intracellular compartments such as the nucleus [63]. In short, too big NPs cannot efficiently enter the cell, whereas too small particles cannot remain and accumulate inside the tumor after translocation through the wide fenestration of the tumor endothelium [64].

\section{Transfection \& target delivery}

An intracellular conformational change in the NPs is another problem in efficient targeting. Internalization of quantum dors into cells by cationic liposomes such as lipofectamine complexes formed aggregates in the cytoplasm [65]. Fluorescent semiconductor quantum dors (alloy nanocrystalline colloids such as $\mathrm{CdSel}$

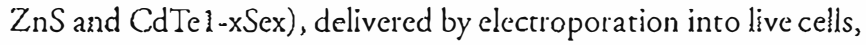
formed similar aggregates of up to $500 \mathrm{sum}$ in diameter rather than being delivered individually. Aggregates of quantum dots were observed both inside and outside of the cell even when crosslinked with bovine serum albumin coat and delivered via electroporation. This suggests that the stabilization of surface ligand is not suffcient to prevent aggregation and that the applied electric potential induced quantum dot aggregation [32]. A major limitation in most of the NP delivery strategies is the difficulty of achieving active targeting of specific subcellular organelles after entry into the cell. The surface of the NPNPs should be modified to improve cellular uptake and to allow specific subcellular defivery [29].

\section{Disparity of the results between in vitro \& in vivo}

Various studies demonstrated a high discrepancy in results between in vitro and in vivo experiments. In the authors' group, two examples reflected these discrepancies. In 2005, Maksimenko tt al. used two types of nanospheres carrying AS-ONs targeting EWS/Fli-l oncogene and found that borh were inefficient in vitro (no inhibition of $\mathrm{mRNA}$ and protein expression). However, the lack of the type 2 nanosphere efficiency was not due to their inability to cross the cell membrane, as their intra cellulat presence was demonstrated by confoncal analysis; but NPs might be cnerapped in an inefficient cellular compartment within the cell. Nevertheless, both cypes once injected in mime by int ratumoral rouce showed a significan, bu incomplete, inhibition and only partial mRNA inhibition was observed. Once injected in ravenously, only cype 2 formulation was found 10 be efficiem [2].

In 2011, Raouane et al. conjugated siRNA against RETTPTC' oncogene with seyuatene and found that the NPs are efficient in vivo but not in witro. "The aurbors postulated that in cell culture conditions, the limited enzymatic content did not allow the cleavage of the squalene needed for the disaggregation of NI's before further recognition of mRNA secquence :3j. 


\section{Advantages \& uses of squalene NPs}

Many different cationic lipids have been synthesized and tested for transfection of genes into cells. Cationic complexes have advantages of nonimmunogenic compared with viral vectors but the problems of low efficiency and cyrotoxicity of cationic lipicls could not be ignored [66]. Cationic cholesterol derivatives are composed of three distinct parts: a cholesteryl skeleton, a cationic amino group and a linker arm between the cholestery! skcleton and cationic amino group. Derivatives with different combinations of these parts were reported, and some have high transfection efficiency [67]. Among them, cholesteryl-3b-carboxyamidoethylene- $N$-hydroxyethylamine, a cationic lipid with a hydroxyethyl group at the amino terminal showed the most efficient rransfecrion efficiency for plasmid DNA (pDNA) and antisense oligodeoxynucleotide delivery [68].

The use of neutral cholesterol derivatives such as squalene was used as a safe alternate as drug carricr biomaterials for several anticancer molecules as gemcitabine [69] and more recently by the authors for siRNA [3]. Squalene have several advantages such as being naturally present in the body, precursor of cholesterol, used as excipient in several pharmacological preparations and a nonionic nontoxic biocomparible vector [69). A squalenoyl conjugate of siRNA RET/PTCl, the junction oncogene frequently found in papillary thyroid carcinoma, was synthesized. The acyclic isoprenoid chain of squalene has been covalently coupled with siRNA $\mathrm{RET} / \mathrm{PTCl}$ at the 3 -terminus of the sense strand via maleimide - sulfhydryl chemistry. Squalene NPs (size $=165 \pm 10 \mathrm{~nm}$ ) hiring siRNA RET/P'TCl display a significant regression of tumor growth (i.e., 70\%) in vivo paralleled with in hibition of RETY PTC1 oncogene and oncoprocein expressions in papillary thyroid carcinoma [3]. However, mechanism of action should be investigated, as the same NPs show relatively low cellular uptake in vitro. Improvements in squalene-based nanoformulations can be done by grafting on their surface-specific ligands recognized by tumor cells, in order to improve their efficiency borh in vitro and in vivo.

\section{Expert commentary \& five-year view}

Despitc the recent progress in cancer treatment, a considerable number of patients relapses and develops recurrene resistance.
Therefore, siRNAs could constitute an area of important research in emerging therapies alone or as combined treatment. The furst siRNAs discovered in mammalian cells and the enormous porential of these biological molecules to be used as drugs have been described for the first time in 2001 [70]. Nowadays, if we look at the ongoing clinical trials, we can be surprised to find how many therapeutic siRNAs are already in Phase II and III [101!. Naked siRNAs are used for local treatments in a large number of different diseases such as age-related macular degeneration, melanoma, intraocular pressure, however, for cancer treatment, naked siRNAs do not spontaneously enter either into the cells in culture or tumor tissuc. To efficiently deliver siRNAs, several strategies were developed using nanocartiers, although only two NPs encapsulating siRNA are actually on early Phase I for patients with neoplastic pathology. This is probably due to the toxicity related to the polymers or compounds used to generate the nanovectors. Much more effort should be done exploring new biological materials (such as lipids, cholesterol and squalene) in order to substitute roxic polymers and improve the number of therapeutic siRNAs that could be delivered. The high specificity of siRNAs is the gold standard characteristic of these potential drugs; hence, an individual therapy related to genomic difference from one patient to another can be now much more realistic within the next 5 years. Furthermore, the synthesis of covalently bound siRNAs with natural lipicis or relared compounds able to rearrange and form NPs (i.e., squalene) could be a new strategy to improve the encapsulation yield, and consequently to reduce frequency and administration doses, fundamental for patients' wellbeing and comfort.

Our point of view is that therapeutic potential of siRNA is not yet enough exploited and this because of not yet weil optinized delivery systems. In the next 5 years, we can expect that new nanoformulations will be conceived and can scale up to clinical trials very quickly.

\section{Financial \& competing interests disclosure}

This work was supported by funding of the Agence Nationale du Cincer, Pragramme P2N, Nanosgualonc, no.: NANO 00301. The authors bave no orher relewant affiliarions or financial involvement with any organization or entity with a financial interest in or financial conflict with the subject matter or materials discussed in the manuscript apart from those disclosed. No writing assistance was utilized in the production of this manuscript.

\section{Key issues}

- RNAi offers promising new opportunities to very specifically target the genes deregulated in various pathologies including cancer.

- Naked antisense oligonucleotides and siRNA are relatively unstable in the blood in their native forms, as are degraded by nucleases due to short half-life of few minutes and are rapidly cleared from the body by renal excretion or may also aggregate with serum proteins.

- A wide variety of approaches including viral as well as nonviral delivery systems have been investigated to enhance the target cell siRNA uptake and silencing potency in vivo.

- Physicochemical properties of the engineered nanoparticles should be considered while designing a nanomedicine for optimal intracellular upiake and targeting with the aim of being capable to reach its biological target with high efficiency and specificity.

- This review helps to understand the parameters that are important to obtain an efficient siRNA delivery system in terms of charge, size, dose and administration route.

- Four major types of nanoparticles are known to deliver the oligonucleotides: nanoplexes, polyplexes, fipoplexes and micelles. This review describes briefly the characteristics of each type.

- In out opinion, much more effort should be done exploring new biological materials (such as lipids, cholesterol and squalene) in order to substitute toxic polymers and improve the number of therapeutic sirna that could be delivered. 


\section{Ali, Urbinafi, Raouane \& Massaad-Massade}

\section{References}

Papers of special notc have been highliglited as: - of interese

- of considerable inerest

1 Pricur A, Tirode F, Cohen P, Delartre O. EWS/FLL-] silencing and gene profling of Ewing cells reveal downstream oncogenic partways and a crucial role for repression of insulin-like growth factor binding prorein 3 . Mol. Cell. Biol. 24(16), 7275-7283 (2004).

2 Maksimenk A, Polard V, Villcmeur M et al. In vivo porentialities of EWS-Fli- 1 targeted antisense oligonucleotides-nanospheres complexes, Ann. NY Acad. Sci. 1058, 52-61 (2005).

3 Raouanc M, Desmacle D, Gilbert-Siricix M et al. Synthesis, characterization, and in vivo delivery of siRNA-squalene nanoparticles rargeting fusion oncogene in papillary thyroid carcinoma. J. Med. Chem. 54(12), 4067-4076 (2011).

- The new efficient squalene nanoparticles (NP's) are fruitful to deliver siRNA up to their target leading to significant mRNA and protein inhibition.

4 Yoshizawa $T$, Hatcori Y, Hakoshima M, Koga K, Maitani Y. Folace-linked lipid-based nanoparticles for synthetic siRNA delivery in KB tumor xenografrs. Eur. J. Pharm. Biopharm. 70(3), 718-725 (2008).

5 Kim SH, Jeong JH, Lee SH, Kim SW, Park TG. Local and sysemic delivery of VEGF siRNA using polyelectrolyec complex micelles for effective treatmenc of cancer. J. Control. Release 129(2), 107-116 (2008).

6 Schiffelers RM, Ansari A, Xu \} et al Cancer siRNA therapy by rumor selecrive delivery with ligand-targeted sterically stabilized nanoparticle. Nucleic Acicls Res. 32(19), el 49 (2004).

- Describes one of the first studics encapsulating siRNA in NPs for a selective delivery.

7 Cubillos-Ruiz JR, Englc X, Scarlert UK et al. Polyethylenimine-based siRNA nanocomplexes reprogram cumor-associated dendritic cells vin 'TIRS to elicit therapeutic ancitumor immunity. J. (lin. Inuss. 119(8), $2231 \ldots 2244$ (2009).

8 Duxbury MS, ho H, Benois E, Zinner MJ, Ashley SW, Whang BE. RNA ineeference rargeting focal adhesion kinase enhances pancreatic adenocilcinoma gemcirabine chamoscnsicivity. Biochim. Biophys. Res. Commun. 311(3), 786m.792 (2003).

9 Migner A. Cellular delivery in vitro of siRNA-based therapeutics. (urr: $\mathrm{P} / \mathrm{h}(\mathrm{mm}$. Des. 14(34), 3603\%3619 (2008).

10) Halder J, Kamat AA, banden CN J o $a$. Focal adhesion kinasc targeting using in wino shorr interfering RNA delivery in neurral liposomes for ovarian carcinoma therapy. Clin. Cancer Res. 12(16), 4916-4924 (2006).

11 Sourschek J, Akinc A, Bramlage B or al. 'Therapeuric silencing of an endogenous gene by systcmic administration of modificd siRNAs. Nature 432(7014), 173-178 (2004).

-. Explains the main issues related to in vivo siRNA inefficacy and how we can circumvent them modifying siRNA structure.

12 Kuo WT, Huang HY, Huang YY Intracellular trafficking, metabolism and toxiciey of currene gene carriers. Curr. Drug Metab. 10(8), 885-894 (2009).

13 Akhirar S, Agrawal S. In vivo studics with antisense oligonucleorides. Tiends Pharmacol. Sci. 18(1), 12-18 (1997).

14 Walder RY, Walder JA. Role of RNase Hin hybrid-arrested translation by antisense oligonucleotides. Proc. Natl Acad. Sci. USA 85(14), 5011-5015 (1988).

15 Pai SI, Lin YY, Macaes B, Meneshian A Hung C.F, Wu TC. Prospeces of RNA ine erference therapy for cancer. Gene Ther. 13(6), 464m477 (2006).

16 de Fougeroilles $A$, Vornlocher $H P$, Maraganore J, Lieberman J. Interfering with diseasc: a progress report on siRNA-based therapeucics. Natr. Rev. Drug Discov. 6(6), 443-453 (2007).

17 Fuchs $U$, Borkharde $A$. The application of siRNA rechnology to cancer biology discovery. Adu. Cancer Res. 96, 75-102 (2007).

18 De Pauła D, Bentley MV, Mahato RY. Hydrophobization and bioconjugation for cnhanced siR.NA delivery and rargering. RNA 13(4), $431-456$ (2007).

19 Ryther RC, Flynt AS, l'hillips JA 3rd, Pacton JG. siRNA cherapeurics: big potential from small RNAs. (icne' Ther: 12(1), 5-11 (2005).

20 Underhill DM, Orinsky A. Phagocyrosis of microbes: complexiry in action. Amm. Reu. lmmunol. 20, 825...852 (2002).

21 Juliano $R$, Bauman J, Kang $H$, Ming $X$. Biological bartiers to cherapy with antisense and siRNA oligonucleorides. Mol. P/arm. 6(3), 686 $\ldots 95$ (2009)

22 Kricg AM. CpC mocifs in bacterial DNA and their immune effeces. Amm. Rew Immmonl. 20, 709) 760 (2002).

23 Zímecnik ], Vargoví L., Homola A, Kodec R, Sytová E. lixcracellular matrix sylycoproseins and diffusion barriers in human astrocytic tumours. Neuropathol. Appl. Neurobiol. 30(4), 338-350 (2004).

24 Dai Z, Zhang Q, Wang Z, Zhang Z, Guo P, Zhao D. Hcmagglutinating virus of Japan envelope (HVJ-E) can enhance the immune responses of swine immunized with killed PR.RSV vaccine. Biochem. Biopbys. Res. Commun. 415(1), 1-5 (2011).

25 L.v H, Zhang S, Wang B, Cui S, Yan J. Toxicicy of cationic lipids and cationic pelymer's in gene delivery. J. Control. Release 114(1), 100-109 (2006).

26 Mowa MB, Crowther C, Arburhuor ?. Therapeucic porential of adenoviral vectors for delivery of expressed RNAi activators. Expert Opin. Drug Deliv. 7(12), 1373-1385 (2010).

27 Wang \}, Faust SM, Rabinowitz JE. The next step in gene delivery: molecular engineering of adeno-associated virus serotypes. J. Mol. Cicll. Cardiol. 50(5), 793-802 (2011).

28 Zaldumbide $A$, Hoeben RC. How nor to be seen: immune-evasion scrategies in gene therapy. Gene The; 15(4), 239-246 (2008).

29) Chou LY, Ming K, Chan WC. Stratcgies for the incracellular delivery of nanoparticles. Chem. Soc. Rev. 40(1), 233 ‥245 (2011).

30 Kievit FM, Veiseh O, Bhatcarai $N$ et al. PEI-PEG-Chirosan Copolymer Coated liron Oxide Nanoparricles for Safe Gene Delivery: synthesis, complexation, and transfection. Adv. Funct. Mater. 19(14), 2244-2251 (2009).

31 Yezhelyev MV, Qi L, O'Regan RM, Nie S, Gao X. Proton-sponge coated quantum dors for siRNA delivery and intracellular imaging. J. Am. Chem. Soc. 130(28), 9006-9012 (2008).

32 Derfus AM, Chen AA, Min DH, Ruoslahti E, Bharia SN. Targered quantum dor conjugates for siRNA delivery. Bioconjug. (hem. 18(5), 1391-1396 (2007).

33 Stoltenburg R, Reincmann C, Strehlizz. B. SELEX - a $($ evolucionary method to gencrate high-affinity nuclcic acid ligands. Biomol. Ling. 24(4), 381-403 (2007).

34 Zhang Y, Thang YF, Bryant J, Charles $A$, Boado RI, Pardridge W/M. Intravenous RNA incerference gene therapy targering the human cpidermal growth factor receptor prolongs survival in int ractanial brain cancer. Cliss Comer Re's. 10(11), 3667-3677 (2004).

35 Caroc ML, looresi RM, Carcia CD, Esplandiu MJ, Giacomelli C CE. Electrostatio and hydrophobic inceractions involved in CNT biofunctionalization with short ss. BNA.J. Phys. Chem. C. Nanomater: Interfices 114(10), 4459).4465(2.010). 


\section{Nanoparticles in SiRNA delivery for cancer therapy}

36 Kakizawa Y, Furukawa S, Ishii A, Karaoka K. Organic-inorganic hybrid-nanocarricr of siRNA constructing through the selfassembly of calcium phosphate and PEG-based block aniomer. J. Control. Releuse $111(3), 368-370$ (2006).

37 de Wolf HK, Snel CJ, Verbaan FJ, Schiffelers RM, Hennink WE, Storm G. Effect of cationic carriers on the pharmacokinetics and tumor localization of nucleic acids after intravenous administration. Int. J. Pham. $331(2), 167-175$ (2007).

38 Vabaan EJ, Oussoren C; Snei CJ, Crommelin DJ, Hennink WE, Storm G. Steric stabilization of poly (2-(dimechylamino) echyl mechacrylarc)-based polyplexes mediates prolonged circulation and tumor targeting in mice. J. Gene Med. 6(1), 64-75 (2004).

39) de Martimprcy H, Bertrand JR, Fusco A et al. siRNA nanoformularion against the ret/PTC 1 junction oncogene is efficient in an in vivo model of papillary chyroid carcinoma. Nucleic Acids Res. 36(1), e2 (2008).

- An example of efficient NPs to inhibit tumor growth by preserving in vivo stability of siRNA with sustained delivery to tumor tissue.

40 Dubey PK, Mishra V, Jain S, Mahor S, Vyas SP. Liposomes modificd with cyclic RGD peptide for tumor targecing. J. Drug Trarget. 12(5), 257-264 (2004).

41 Noguchi $Y, W u$ J, Duncan R ct al. Early phase tumor accumulation of macromolecules: a great difference in clearance rare between tumor and normal tissucs. Jpn. J. Cancer Res. 89(3), 307-314 (1998).

12 Greish K. Enhanced permeabilicy and retention of macromolecular drugs in solid tumors: a royal gate for targeted anticancer nanomedicines. J. Drug Terget. 15(7-8), 457-464 (2007).

4.3 Oliveira S, van Rooy I, Kranenburg (), Storm (;, Schiffelers RM. Fusogenic peptides enhance endosomal escape improving siRNA-induced silencing of oncogenes. Int. J. Pharm. 331 (2), $211 \ldots 214$ (2007).

in (ho YW, Kim JI), Park K. Polycation gene delivery systems: cscape from endosomes io cytosol. J. Pharm. Phatrmecol. 55(6). $721-734(200.3)$.

as Wu SY, McMillan NA. L.ipidic syscems for in uruo siRNA delivery. AAPS J. $11(4)$, 6.39-652 (2009).

is Whichead $\mathrm{KA}$, langer $\mathrm{R}$, Anderson $\mathrm{WC}$. Knocking down barriers: advances in siRNA delivery. Nitt. Reu 1. rrug Discou. 8(2), 129) 138 (2009).
- Helps to have a quick and detailed overview on siRNA mechanism of action, the mean issues for their in vivo efficiency and resolutions using various delivery systems.

(1) Frank-Kamenersky $M$, Grefhorst $A$, Anderson NN et al. Therapeuric RNAi targeting l'CSK9 acurcly lowers plasma cholesterol in rodents and LDL cholesterol in nonhuman primates. Proc. NettlAcad. Sci. USA 105(33), 11915-11920 (2008).

48 Raouane M, Desmaële D, Urbinati $G$, Massaad-Massade L, Couvreur P. Lipid conjugated oligonucleotides: a uscful strategy for delivery. Bioconjug. Chem. doi:10.1021/bc200422w (2012) (Epubs ahead of princ).

49 de Martimprey H, Bertrand JR, Malvy C, Couvreur P, Vauchier C. New core-shell nanoparticules for the intravenous delivery of siRNA to cxperimental thyroid papillary carcinoma. Pharm. Res. 27(3), 498-509 (2010).

so Sorcnsen DR, Leirdal M, Sioud M. Gene silencing by systemic delivery of syntheric siRNAs in adult mice. J. Mol. Biol. 327(4), 761-766 (2003).

s1 Landen CN Jr, Chavez-Reyes A, Bucana C et al. Therapeutic EphA2 gene targeting in vivo using neucral liposomal small interfering RNA delivery. Cincer Res. 65(15), 6910-6918 (2005).

s2 Karaoka K, liaka K, Nishiyama N, Yamasaki Y, Oishi M, Nagasaki Y. Smart polymeric micelles as nanocarriers for oligonucleorides and siRNA delivery. Nuclcic Acids Symp. Ser. (Oxf). 49, 17-18 (2005).

53. Arnida, Nishiyama N, Kanayama N, Jang WD, Yamasaki Y, Karaoka K. PEGylated gene nanocarriers based on block catiomers bearing echylenediamine repeating units directed to remarkable enhancement of phocochemical transfection. J. Control. Release 115(2), 208-215 (2006).

54 Oishi M, Nagasaki Y', Iraka K, Nishiyama N, Kataoka K. Lactosylated poly (ethylenc glycol)-siRNA conjugatc through acid-labile $\beta$-rhiopropionace linkage to construce pH-sensitive polyion complex micelles achieving enhanced gene silencing in hepatoma cells. J. Am. (heom. Soc. 127(6), $1624 \cdots 1625$ (2005).

55 Hassan \% lemkine CHF, Lerbacher l' et al. l.ipid-medianed siRNA delivery downregulates exogenous gene expression in the mouse brain at picomolar levels. J. (Genc Med. 7(2), 198-207 (2005).

56 Rudolph C, Schillinger U, Orriz A et al. Acrosolized manogram quanticies of plasmid DNA mediate highly efficient gene delivery to mouse airway epithclium. Mol. Ther: 12(3), 493-501 (2005)

57 Höbel $S$, Koburger I, John M et al. Polychylenimine/small interfering RNA-mediated knockdow'n of vascular endorhelial growth factor in vivo excres anti-tumor effects synergisticaliy with Bevacizumab. J. Gene Med. 12(3), 287-300 (2010).

58 Günther M, Lipka J, Malek A, Gursch D, Kreyling W, Aigner A. Polyechylenimines for RNAi-mediared gene targeting in vivo and siRNA delivery to the lung. Eur: J. Pharm. Biopharm. 77(3), 438-449 (2011).

59 Plank C, Mechrle: K, Sroka EC Jr, Wagner E. Acrivation of the complement system by syncheric DNA complexes: a potential barrier for int ravenous gene delivery. Ifum. Gene Ther. 7(12), 1437\%1446 (1996).

60 Li SD, Huang L. Stcalth nanoparricles: high density but sheddable PEG is a key for zumor targeting. J. Control. Release 145(3), 178-181 (2010).

$6)$ Perros RA, DeSimone JM. Strategies in the design of nanoparticles for therapeutic applications. Nat. Rev. Drug Discov. 9(8), 615-627 (2010).

-. Focuses on the design of NPs for therapeutic applications while considering their physical characteristics to target organ or organelle sites.

62 Dreher MR, Liu W', Michelich CR, Dewhirst MW, Yuan F, Chilkoti A. Tumor vascular permeability, accumulation, and penceration of macromolecular drug carriers. J. Natl. Cancer Inst. 98(5), 335-344 (2006).

. The authors give information regarding penetration, permeability and macromolecules accumulation according to the molecular weight in the tumor tissuc.

6.3 Bartlet DW, Davis ME. Physicochemical and biological characterization of targered, nucleic acid-containing nanoparticles. Bioconjug. Chern. 18(2), 456-468 (2007).

Gá Marsumura Y, Maeda H. A new concept for macromolecular therapcucics in cancer chemotherapy: mechanism of tumoritropic accumulation of proteins and the ancinumor agene smancs. Cimeer Res. 46(12 Pe 1), 6.387-6.392 (1986).

65 Derfus AM, Chan WCW Bharia SN. incracellukar delivery of quansum dots for live cell labeling and organclle tracking. Adt: Matter: 16(12), 961-966 (2004).

gr lee $Y$, Koo H, lim YB, Lee Y. Mo H Park JS. New cationic lipids for gene transfer with high chficincy and Jow toxicity: Teshape cholesterol ester derivarives. Bioorg. Med. Chcm. Litt. 14(30), 2637-2641 (2004). 


\section{Ali, Urbinati, Raouane \& Massaad-Massade}

67 Percot A, Briane D, Coudert Ret al. A hydroxycthylated cholesterol-based cationic lipid for DNA delivery: effecr of condicioning. Int. J. Pharm. 278(1), 143-163 (2004).

68 Noguchi S, Hirashima N, Furuno T; Nakanishi M. Remarkable induction of apoprosis in cancer cells by a novel cationic liposome complexed with a bcl-2 antisense oligonucleocide. J. Control. Releuse 88(2), 313-320 (2003).

69 Reddy L.H, Renoir JM, Marsaud V, leperre-Mouelhi S, Desmaële D, Couvreur P. Anticancer efficacy of soulualenoyl gemcitabine nanomedicine on 60 human cumor cell panel and on experimental tumor. Mol. Pharm. 6(5), 1526-1535 (2009).

70 Elbashir SM, Harborth J, Lendeckel W, Yalcin A, Weber K, 'Tuschl'T. Duplexes of 21 -nucleotide RNAs mediare RNA incerference in cultured mammalian eclls. Nature 4l 1(6836), 494-498 (2001).

71 Lamber $G$, Fartal E, Pinco-Alphandary $H$ Gulik A, Couvreur P.

Polyisobutylcyanoacrylate nanocapsules containing an aqueous core as a novel colloidal carrier for the delivery of oligonucleotides. Pharm. Res. 17(6), 707--714 (2000).

72 Grzelinski $M$, Urban-Klein B, Marters $T$ et al. RNA interference-mediated gene silencing of pleiorrophin through polyerhylenimine-complexed small interfering RNAs in vivo exerts antitumoral cffects in glioblastoma xenografes. Hum. Gene Ther. 17(7), 751-766 (2006).

73 Koga K, Hattori Y, Komori M et al. Combination of RET siRNA and irinocecan inhibiced the growth of medullary thyroid carcinoma TT cells and xenografes via apoptosis. Cancer Sci. 101(4), 941-947 (2010).

\section{Website}

101 www.clinicaltrials.gov.com 